\title{
Prevalence of abnormal serum 25- hydroxyvitamin $D$ and its association with hemoglobin level in pre dialysis CKD patients: a cross-sectional study from Himalayan country
}

\author{
Shiv Kumar Sah ${ }^{1,3^{*}}$ and Laxman Prasad Adhikary ${ }^{2}$
}

\begin{abstract}
Background: CKD has been recognized as risk factors for 25(OH) D deficiency, and Low levels of 25(OH) D have been suggested to be a trigger factor of decreased level of $\mathrm{Hb}$. However, there is lack of information about the magnitude of $25(\mathrm{OH}) \mathrm{D}$ deficiency and $\mathrm{Hb}$ level in Nepalese CKD patients. Therefore, the aim of present study was to investigate the prevalence of abnormal $25(\mathrm{OH}) \mathrm{D}$ in non-dialyzed CKD patients, and further to examine its association with $\mathrm{Hb}$ level.

Methods: In this cross-sectional study, we examined 172 clinically stable patients with an eGFR at CKD stage2-5 not on dialysis. Serum $25(\mathrm{OH}) \mathrm{D}, \mathrm{Hb}$, levels were evaluated as a core variables and the other variables such as age, sex, co-morbidities (HTN, DM), eGFR, Hb, iPTH, serum phosphate, albumin, calcium, and phosphate level were evaluated as a covariates. Serum $25(\mathrm{OH}) \mathrm{D}, \mathrm{Hb}$ levels and the factors associated with $25(\mathrm{OH}) \mathrm{D}$ level were evaluated.

Results: The estimated prevalence of abnormal $25(\mathrm{OH})$ D metabolite $(<30 \mathrm{ng} / \mathrm{mL})$ in this predialysis patients were (87.8\%), with 32 and 55.8\% deficiency and insufficiency 25(OH) D metabolite, respectively. On regression analysis, serum $25(\mathrm{OH}) \mathrm{D}$ was positively associated with male subjects $(P=0.02)$, serum albumin $(P=0.002)$, and eGFR $(P=$ 0.042), while inversely associated with age $(P=0.006)$, $\mathrm{PTTH}(P=0.025)$. Hb concentration was found to be positively correlated with $25(\mathrm{OH}) \mathrm{D}(P<0.05)$ in both univariate as well as in multivariate analysis.

Conclusion: A high prevalence of abnormal 25(OH) D metabolite was observed in early CKD patients. Our study shows that lower level of 25(OH) D level are associated with lower level of $\mathrm{Hb}$ and higher level of iPTH, and could play a role in the development of anemia and hyperparathyroidism.
\end{abstract}

Keywords: CKD, 25(OH) D, Hemoglobin

\section{Background}

Chronic kidney disease (CKD) has been a growing health burden worldwide [1-4], and the patients with CKD continue to suffer from a wide range of complication including electrolyte imbalance, fluid overload, bone and mineral metabolism disorder to anemia $[5,6]$. Anemia

\footnotetext{
* Correspondence: phrshiv@gmail.com

'Department of Pharmacy, Little Buddha College of Health Science,

Purbanchal University, Minbhawan, Kathmandu, Nepal

${ }^{3}$ Little Buddha College of Health Science, GPO Box 26508, Minbhawan,

Kathmandu, Nepal

Full list of author information is available at the end of the article
}

secondary to CKD is a complex complication which often goes untreated resulting in high morbidity, mortality, and cost of health care [7]. The incidence and prevalence of anemia increases as kidney function declines, and up to $50 \%$ of CKD patients not requiring chronic dialysis [7-10]. Although, erythropoietin deficiency, iron deficiency, and malnutrition-inflammation may have potential for the development CKD associated anemia, recent studies have indicated that $25(\mathrm{OH}) \mathrm{D}$ has pleiotropic effects on bone and mineral disorder [11, $12]$, and decreased level of $25(\mathrm{OH}) \mathrm{D}$ levels have been

(c) The Author(s). 2019 Open Access This article is distributed under the terms of the Creative Commons Attribution 4.0 International License (http://creativecommons.org/licenses/by/4.0/), which permits unrestricted use, distribution, and 
associated with low hemoglobin concentration in the subjects with normal renal function as well as in the patients with early chronic CKD [13-15]. Available literature suggests that high prevalent of $25(\mathrm{OH}) \mathrm{D}$ deficiency may be an important contributor to secondary hyperparathyroidism, which is harmful to bone health [16, 17]. Recently, epidemiologic studies have identified a high prevalence of suboptimal $25(\mathrm{OH})$ D levels in pre dialysis CKD patients $[18,19]$. However, to date, such problem has not been extensively examined in Nepalese CKD population. Therefore, the present study was attempted to highlight the status of $25(\mathrm{OH})$ D level in CKD patient not on dialysis, and further to examine whether the deficiency of $25(\mathrm{OH}) \mathrm{D}$ independently associated with the lower hemoglobin level.

\section{Methods}

\section{Study design and duration}

This cross-sectional study was carried out between June 2016 to May 2017 in the patients visiting outpatient nephrology unit at Kathmandu medical and teaching hospital.

\section{Study population and selection}

A total 172 patients who met the inclusion criteria were included in the study. To be eligible for the study, individuals who were $\geq 18$ years of age and have had measurement of serum creatinine and $25(\mathrm{OH}) \mathrm{D}$ and urine albumin creatinine. Clinical stable and with a diagnosis of CKD stage 2-5 who were not on dialysis were recruited for the study. The exclusion criteria included renal replacement therapy, a use of prescription based use $25(\mathrm{OH})$ D supplementation within 12 month of screening and phosphate binders.

\section{Variables of interest}

The core variables of interest of this study was $25(\mathrm{OH})$ $\mathrm{D}$ level and hemoglobin concentration. The following covariates included in statistical analysis: age, sex, comorbidities (HTN, DM), biochemical laboratory test including eGFR, Hb, iPTH, serum phosphate, albumin, calcium, and phosphate .

\section{Estimation of GFR}

GFR were estimated by using MDRD-4 equation [20]:

$$
\mathrm{GFR}=175 \mathrm{x}(\mathrm{SCr})^{-1.154} \mathrm{x}(\mathrm{age})^{-0.203} \mathrm{x}(0.742 \text { if female })
$$

GFR units are $\mathrm{mL} / \mathrm{min} / 1.73 \mathrm{~m}^{2}$. CKD staging was done as recommended by the National Kidney Foundation $[21]$.

\section{Estimation of 25(OH) D and hemoglobin}

Electrochemiluminescence immunoassay (ECLIA) test was used to measure the level of $25(\mathrm{OH}) \mathrm{D}$ and cyanmethemoglobin method for the estimation of $\mathrm{Hb}$ level .

Based on the opinion of most experts and available literature [15, 22], 25(OH) D was categories in three groups: vitamin D deficiency if serum $25(\mathrm{OH}) \mathrm{D}$ levels $<20 \mathrm{ng} / \mathrm{mL}$, vitamin D insufficiency as $25(\mathrm{OH}) \mathrm{D}$ levels of $20-30 \mathrm{ng} / \mathrm{mL}$, and vitamin D sufficiency as $25(\mathrm{OH}) \mathrm{D} 3$ levels $\geq 30 \mathrm{ng} / \mathrm{mL}$. A cut-point less than $30 \mathrm{ng} / \mathrm{mL}$ of $25(\mathrm{OH}) \mathrm{D}$ was considered abnormal. All samples analyzed at a KMC-teaching hospital laboratory were utilized for the study.

\section{Data analysis}

Continuous variables were expressed as mean \pm SD or median \pm interquartile range for skewed data. Based on $25(\mathrm{OH}) \mathrm{D}$ levels, the patients were categorized into three groups (deficiency: $<20 \mathrm{ng} / \mathrm{mL}$, insufficiency: 20 30 and sufficiency: $>30 \mathrm{ng} / \mathrm{mL}$ ). The significance of differences among continuous variables was performed by using One-way Analysis of Variance (ANOVA), and the significance of association for categorical measure was performed by Pearson's Chi-square ( 2). Linear regression analysis were performed to examine the relationship between each $25(\mathrm{OH}) \mathrm{D}$ metabolite and clinical parameter including age, sex, calcium, phosphate, serum albumin, and serum iPTH. Multiple regression analysis was performed to assess the combined effects of clinical variables on serum level of each $25(\mathrm{OH})$ metabolite. Some missing data for iPTH, $\mathrm{Ca}$ and Phosphorous were imputed using multiple imputation regression method and were considered for analysis. A $p$ value $<0.05$ considered at level of significance for all statistical analysis.

\section{Ethical issues}

Study protocol was approved by the institutional review board (IRB) of Kathmandu University and Teaching Hospital. Participants were well aware of the investigation and those who showed willingness to participate in the study voluntarily were consented prior to data collection.

\section{Results}

Table 1 presents the prevalence of abnormal 25(OH)D. Total 172 patients were enrolled for the study. Prevalence of abnormal $25(\mathrm{OH}) \mathrm{D}(<30 \mathrm{ng} / \mathrm{mL})$ was $87.8 \%$ (95\%; LL 82.2\%-UL92.2\%), with deficiency 32\% (95\%CI; LL25.1\% -UL38.9\%), and insufficiency (55.8\%) (95\%CI: LL-46.8\%-UL-65.7\%).

Baseline characteristic of the enrolled subjects are presented in Table 2. Based on 25(OH) D levels, patients were categorized in three groups: group $1(<20 \mathrm{ng} / \mathrm{mL})$, group $2(20-30 \mathrm{ng} / \mathrm{mL})$ and group $3(>30 \mathrm{ng} / \mathrm{mL})$. 
Table 1 Prevalence of abnormal 25(OH)D

\begin{tabular}{lll}
\hline 25(OH)D & $\begin{array}{l}\text { Patients } \\
\mathrm{n}\end{array}$ & $\begin{array}{l}\text { Total }(n=172) \\
\text { Prevalence }(95 \% \mathrm{Cl})\end{array}$ \\
\hline $\begin{array}{l}\text { Abnormal 25(OH)D } \\
\text { 25(OH) D (strata) }\end{array}$ & 152 & $87.8 \%(82.2-92.2)$ \\
$\quad$ i. Deficiency $(<20 \mathrm{ng} / \mathrm{mL})$ & 55 & $32 \%(25.1-38.9)$ \\
ii. Insufficiency $(20-30 \mathrm{ng} / \mathrm{mL})$ & 96 & $55.8 \%(46.8-65.7)$ \\
$\quad$ iii. Sufficiency $(\geq 30 \mathrm{ng} / \mathrm{mL})$ & 21 & $12.2 \%(7.4-17.0)$ \\
\hline
\end{tabular}

Compared with the group 1 and group3, mean ages were significantly higher in group $2(<0.05)$. Similarly, mean $\mathrm{Hb}$ levels were significantly different among the groups, and were found to be progressively increased as the $25(\mathrm{OH})$ levels increased $(P<0.05)$. There were no differences in sex, co -morbidities, SBP, DBP, Calcium, phosphorous, serum albumin, iPTH, eGFR and CKD stages amongst the group $(P>0.05)$.

Table 3 shows the factors associated with serum 25(OH)D. Age, sex, HTN, DM, eGFR, albumin, calcium, phosphorous and $\mathrm{PTH}$ were modeled for the regression analysis. On univariate regression analysis, male subjects $(\beta=.17, P=0.02)$, serum albumin $(\beta=0.23, \quad P=0.002)$, eGFR $(\beta=0.15, P=0.042)$ positively and significantly linked to serum $25(\mathrm{OH}) \mathrm{D}$ level, while age $(\beta=-.210$,
$P=0.006)$, and $\mathrm{iPTH}(\beta=-.17,0.025)$ were inversely and significantly associated.

After adjusting age, sex, HTN, DM, serum albumin, EGFR, Ca, P, iPTH to the multiple regression analysis, only age $(B=-2.3, P=0.009)$, male $(\beta=2.5, P=0.018)$, serum albumin $(\beta=-0.20, P=0.007)$ were found to be associated with $25(\mathrm{OH}) \mathrm{D}$.

On univariate regression analysis, $\mathrm{Hb}$ concentration was found to be significantly correlated with age $(\beta=-0.025$, $p=0.014)$, eGFR $(\beta=0.49, P<0.001), 25(\mathrm{OH}) \mathrm{D}(\beta=0.31$, $P=<0.001)$, iPTH $(\beta=-0.43, P<0.001)$ and serum calcium level $(\beta=0.28, P=<0.001)$. The association between $\mathrm{Hb}$ concentration and serum $25(\mathrm{OH}) \mathrm{D}(\beta=0.14, P=$ $0.034)$ level, serum calcium $(\beta=0.18, P=0.004)$ and iPTH $(\beta=-.20 P=0.008)$ remained significant on multivariate regression analysis) (Table 4 ).

Figure 1 depicts the correlation between 25(OH) D and $\mathrm{Hb}$. Pearson correlation coefficient revealed a significant and positive correlation between the $25(\mathrm{OH}) \mathrm{D}$ and $\mathrm{Hb}(r=0.31, P=<0.001)$.

\section{Discussion}

Recent studies have shown to be a high prevalence of $25(\mathrm{OH}) \mathrm{D}$ deficiency across the nations [23-25]. However, the assessment of $25(\mathrm{OH}) \mathrm{D}$ in CKD population

Table 2 Characteristics of the patients according to serum 25(OH) D level

\begin{tabular}{|c|c|c|c|c|c|}
\hline Variable & $\begin{array}{l}\text { Total } \\
(n=172)\end{array}$ & $\begin{array}{l}\text { Group1 } \\
<20 \\
N=55\end{array}$ & $\begin{array}{l}\text { Group2 } \\
{[20-30]} \\
N=96\end{array}$ & $\begin{array}{l}\text { Group } 3 \\
>30 \\
N=21\end{array}$ & $p$ \\
\hline Age (years) $\pm S D$ & $53.005 \pm 15.33$ & $52.75 \pm 14.94$ & $55.56 \pm 14.75$ & $42.09 \pm 15.33$ & 0.001 \\
\hline Sex, $(\%)$ & & & & & 0.16 \\
\hline male & $123(71.5)$ & $34(19.76)$ & $72(41.86)$ & $17(9.88)$ & \\
\hline Total $(n=172)$ & $49(28.48)$ & $21(12.20)$ & $24(13.95)$ & $4(2.32)$ & \\
\hline \multicolumn{6}{|l|}{ Co-morbidities (\%) } \\
\hline $\mathrm{HTN}(+)$ & $53(30.81)$ & $20(11.62)$ & $10(5.81)$ & $23(13.37)$ & 0.06 \\
\hline $\mathrm{DM}(+)$ & $138(80.23)$ & $43(25.00)$ & $75(43.60)$ & $20(11.62)$ & 0.17 \\
\hline $\mathrm{SBP} \pm \mathrm{SD}$ & $125.76 \pm 15.51$ & $126.96 \pm 16.33$ & $124.58 \pm 15.17$ & $127.86 \pm 15.04$ & 0.63 \\
\hline $\mathrm{DBP} \pm \mathrm{SD}$ & $81.22 \pm 10.94$ & $81.42 \pm 11.74$ & $80.73 \pm 11.00$ & $82.84 \pm 11.35$ & 0.33 \\
\hline $\mathrm{Hb}(\mathrm{mg} / \mathrm{dL}) \pm \mathrm{SD}$ & $12.23 \pm 2.03$ & $11.55 \pm 1.90$ & $12.48 \pm 2.09$ & $12.92 \pm 1.84$ & 0.006 \\
\hline Albumin $(\mathrm{mg} / \mathrm{dL}) \pm \mathrm{SD}$ & $4.05 \pm 0.92$ & $3.97 \pm 0.37$ & $4.08 \pm 0.39$ & $4.16 \pm 0.49$ & 0.10 \\
\hline $\mathrm{Ca}(\mathrm{mg} / \mathrm{dL}) \pm \mathrm{SD}$ & $9.10 \pm 1.19$ & $8.96 \pm 0.89$ & $9.16 \pm 1.41$ & $9.19 \pm 0.70$ & 0.56 \\
\hline$P(m g / d L) \pm S D$ & $3.59 \pm 0.71$ & $3.52 \pm 0.56$ & $3.65 \pm 0.81$ & $3.50 \pm 0.60$ & 0.48 \\
\hline $\mathrm{iPTH}(\mathrm{pg} / \mathrm{mL}) \pm \mathrm{SD}$ & $235.96 \pm 83.43$ & $247.41 \pm 60.25$ & $235.51 \pm 92.79$ & $207.48 \pm 51.32$ & 0.10 \\
\hline $\mathrm{SCr}$ & $2.66 \pm 2.17$ & $3.19 \pm 2.91$ & $2.36 \pm 1.68$ & $2.61 \pm 1.66$ & 0.081 \\
\hline eGFR (ml/min/1.72 $\left.\mathrm{m}^{2}\right)$ & $46.14 \pm 26.52$ & $43.87 \pm 25.59$ & $46.04 \pm 26.49$ & $52.61 \pm 29.28$ & 0.82 \\
\hline CKD stage, n (\%) & & & & & 0.54 \\
\hline Stage $2(e G F R>60)$ & 61 & $19(11.04)$ & $33(19.18)$ & $9(5.23)$ & \\
\hline Stage 3 (eGFR30-59) & 51 & $19(11.04)$ & $28(16.27)$ & $4(2.32)$ & \\
\hline Stage 4 (eGFR 15-29) & 37 & $8(4.65)$ & $23(13.37)$ & $6(3.48)$ & \\
\hline Stage $5(\mathrm{eGFR}<15)$ & 23 & $10(5.81)$ & $11(6.39)$ & $2(1.16)$ & \\
\hline
\end{tabular}


Table 3 Association between 25(OH) D and clinical/biochemical parameter

\begin{tabular}{|c|c|c|c|c|}
\hline \multirow[t]{2}{*}{ Parameter } & \multicolumn{2}{|c|}{ Univariate regression analysis } & \multicolumn{2}{|c|}{ Multivariate regression analysis } \\
\hline & $\beta$ & P & $\beta$ & $P$ \\
\hline Age (years) & -.210 & 0.006 & -2.3 & 0.009 \\
\hline Sex (male) & .178 & 0.02 & 2.5 & 0.018 \\
\hline $\mathrm{HTN}(+)$ & .09 & 0.20 & & \\
\hline $\mathrm{DM}(+)$ & .099 & 0.19 & & \\
\hline $\mathrm{eGFR}\left(\mathrm{ml} / \mathrm{min} / 1.72 \mathrm{~m}^{2}\right)$ & 0.15 & 0.042 & 0.005 & 0.95 \\
\hline Albumin (mg/dL) & 0.23 & 0.002 & 0.20 & 0.007 \\
\hline Calcium (mg/dL) & 0.068 & 0.37 & & \\
\hline Phosphorous (mg/dL) & -.10 & 0.16 & & \\
\hline iPTH (pg/mL) & -.17 & 0.025 & -1.3 & 0.19 \\
\hline
\end{tabular}

has not been in routine practice in the resource limiting country, especially in Nepal. And also the magnitude of such problem has not been addressed properly. To the best of our knowledge this the first study that has been attempted to highlight the status of $25(\mathrm{OH}) \mathrm{D}$ and hemoglobin in patients with CKD stage 1-5 not on dialysis in Nepalese setting.

In the present study, we observed $87.8 \%$ population had abnormal $25(\mathrm{OH})$ D $(<30 \mathrm{ng} / \mathrm{mL})$ level, with $32 \%$ deficiency and $55.8 \%$ insufficiency $25(\mathrm{OH})$ level. In agreement with this finding, most recently in US study, $86 \%$ had suboptimal levels of vitamin $D(<30 \mathrm{ng} / \mathrm{ml})$ [25]. Similarly, previous study [14] in chronic kidney disease demonstrated that $3.11 \%$ had $25(\mathrm{OH}) \mathrm{D}(<10 \mathrm{ng} /$ $\mathrm{mL})$ deficiency, $54.51 \%$ insufficiency $(10-30 \mathrm{ng} / \mathrm{mL})$. Likewise, in a earlier report [26], 57 and 58\% population had $25(\mathrm{OH})$ D insufficiency $(10-30 \mathrm{ng} / \mathrm{mL})$ in CKD stage 3 and 4 respectively; and 14 and $26 \%$ had calcidiol deficiency $(<10 \mathrm{ng} / \mathrm{ml})$ in CKD stage 3 and 4 respectively. These widespread variations in the prevalence of vit $\mathrm{D}$ deficiency may be explained by the number of factors including variation in the degree of renal impairment, co-morbidities and the diversity of the enrolled population in the respective studies.

The pathophysiology of $25(\mathrm{OH}) \mathrm{D}$ deficiency is multifactorial and is varied by race, sunlight exposure, and presence of risk factors such as age, type- 2 diabetes and obesity, and other co-morbidities [13]. Serum levels of vitamin $\mathrm{D}$ metabolites are also affected by several factors including calcium, phosphate, iPTH, and the progression of CKD [23-25].

By linear regression analysis we observed a significant correlation between $25(\mathrm{OH}) \mathrm{D}$ and clinical/biochemical parameter. Age, sex, eGFR, serum albumin and iPTH were found to be significantly correlated with serum $25(\mathrm{OH}) \mathrm{D}$. Further we applied multiple regression to determine the combined influence of these factors on serum level of $25(\mathrm{OH})$, and observed that age, sex and serum albumin was independently associated with serum 25 $(\mathrm{OH}) \mathrm{D}$.

In the present study, we noted that age appeared to be inversely correlated with serum $25(\mathrm{OH}) \mathrm{D}$ and also remained associated in multiple regression analysis, which compiles the results with previous study [23]. Thus, the data imply that age is an important predictors

Table 4 Association between $\mathrm{Hb}$ and clinical/biochemical parameter

\begin{tabular}{|c|c|c|c|c|}
\hline & \multicolumn{2}{|c|}{ Univariate regression analysis } & \multicolumn{2}{|c|}{ Multivariate regression analysis } \\
\hline & $\beta$ & $p$ & $\beta$ & $p$ \\
\hline Age (years) & -.025 & 0.016 & -0.25 & 0.80 \\
\hline Sex (male) & .67 & 0.052 & 0.10 & 0.094 \\
\hline $\mathrm{HTN}(+)$ & .043 & 0.581 & & \\
\hline $\mathrm{DM}(+)$ & 0.090 & 0.174 & & \\
\hline eGFR (ml/min/1.72 m²) & 0.49 & $<0.001$ & 0.27 & $<0.001$ \\
\hline 25(OH) D (ng/mL) & 0.31 & $<0.001$ & 0.15 & 0.022 \\
\hline Albumin (mg/dL) & 0.32 & $<0.001$ & 0.17 & 0.009 \\
\hline Phosphorous (mg/dL) & -0.004 & 0.95 & & \\
\hline $\mathrm{Ca}(\mathrm{mg} / \mathrm{dL})$ & 0.28 & $<0.001$ & 0.20 & 0.002 \\
\hline iPTH (pg/ml) & -0.433 & $<0.001$ & -.203 & 0.008 \\
\hline
\end{tabular}




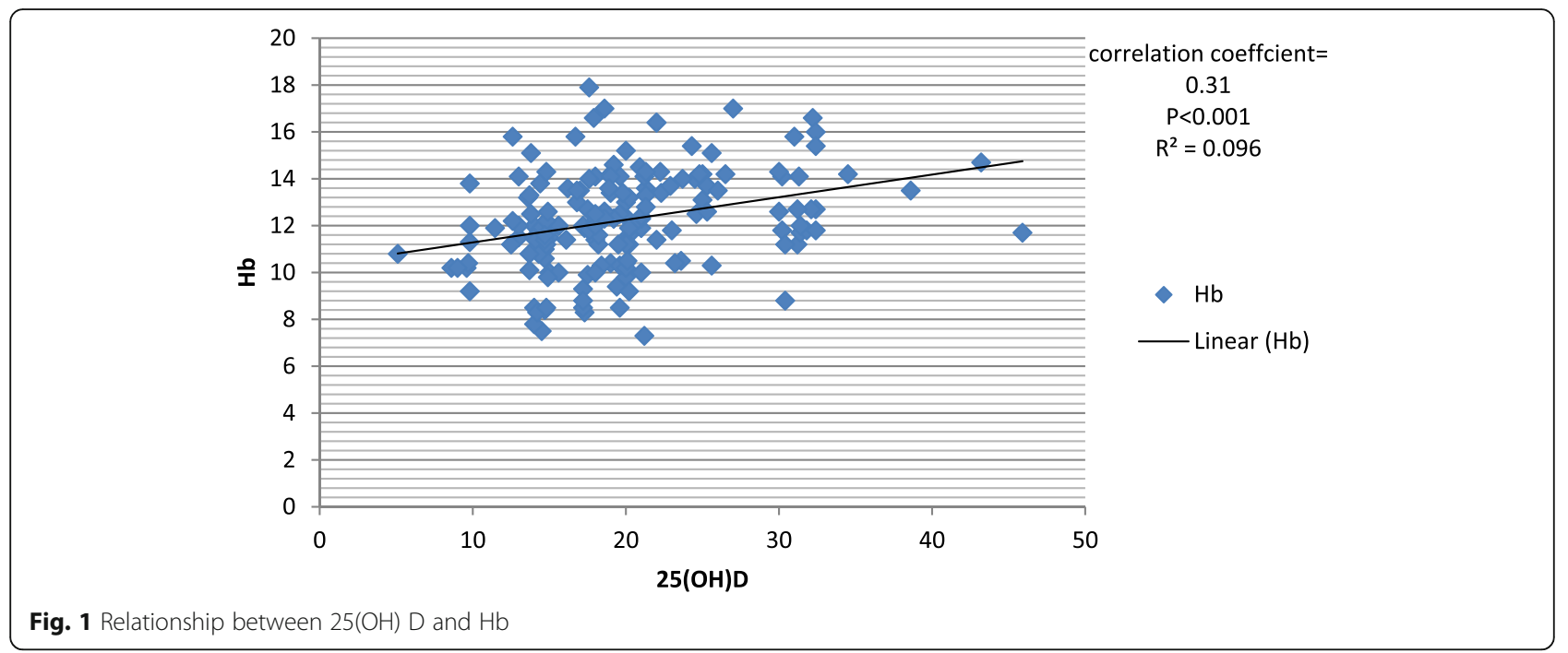

for serum $25(\mathrm{OH}) \mathrm{D}$, where increasing age is associated with the decreased level of serum 25(OH)D. Also we noted that high level of serum $25(\mathrm{OH})$ D level was associated with male gender, and this affirm the result of the previous study of early CKD patients [23].

By general linear regression, there was a significant positive correlation between $25(\mathrm{OH}) \mathrm{D}$ and eGFR. These results supports the observations from the large number of previous studies in which serum $25(\mathrm{OH})$ level decreased as the renal function declined early in the course of CKD $[18,19]$.

In this study, low level of serum albumin level was positively correlated with the low level of $25(\mathrm{OH}) \mathrm{D}$ level; indicating that hypoalbuminemia may be one of the potential contributing factor to the low level of $25(\mathrm{OH}) \mathrm{D}$ levels. It is widely accepted that $25(\mathrm{OH}) \mathrm{D}$ deficiency may lead to hyperparathyroidism in normal individuals [27, 28]. Similarly, the present study shows a significant, inverse relationship between $25(\mathrm{OH})$ D levels and $\mathrm{iPTH}$, indicating that low level of $25(\mathrm{OH})$ $\mathrm{D}$ could influence the high level of $\mathrm{iPTH}$. This finding is consistent with a large number of studies in different populations and suggests that low level of $25(\mathrm{OH}) \mathrm{D}$ could lead to secondary hyperparathyroidism, which is harmful to bone health $[16,17]$. Our study finding also support the concern raised by the K/DOQI guideline that the high prevalent of $25(\mathrm{OH})$ $\mathrm{D}$ deficiency may be an important contributor to the pathogenesis of secondary hyperparathyroidism, which has been largely overlooked in our study population. In the present study, low level of $25(\mathrm{OH}) \mathrm{D}$ was strongly correlated with reduced eGFR; suggesting that deterioration of renal function may be related to the deficiency of $25(\mathrm{OH}) \mathrm{D}$. And the association is congruent with a large number of epidemiologic studies $[14,23,25]$.
In the present study we also attempted to ascertain the association of $\mathrm{Hb}$ with serum $25(\mathrm{OH}) \mathrm{D}$, and other biochemical parameter. The anemia secondary to kidney disease is complex and a number of factors attributes to this pathogenesis [29]. Recently, some studies have reported the positive relationship between serum $25(\mathrm{OH})$ $\mathrm{D}$ and $\mathrm{Hb}$ concentration in general population as well as with chronic kidney disease patients [13, 23]. Although, the exact pathophysiology of this association is unclear, it is believed that $25(\mathrm{OH}) \mathrm{D}$ deficiency could lead to increased risk of reticulocytosis and iron deficiency anemia [30]. In bone marrow there are enormous $25(\mathrm{OH}) \mathrm{D}$ receptors and the presence of high local concentration of $25(\mathrm{OH}) \mathrm{D}$ in hematopoietic tissue is suggested to activate erythroid precursors cell [31].

Our study demonstrated that $\mathrm{Hb}$ concentration significantly, positively correlated with $25(\mathrm{OH}) \mathrm{D}$ age, eGFR and calcium level. Conversely, there was inverse relationship between $\mathrm{Hb}$ and iPTH. Also, after controlling for the other important covariates, the effects of serum $25(\mathrm{OH}) \mathrm{D}$ level, serum albumin, calcium and $\mathrm{iPTH}$ remained significant predictors of hemoglobin. And this association is well described in some recent studies in early CKD population $[14,15]$.

\section{Limitations}

Since, the nature of the study being cross-sectional, the study only allows evaluating the association but could not draw the any conclusion about causal relationship over the time. Thus, an interventional study in a large population is needed to explore the causal relationship between $25(\mathrm{OH}) \mathrm{D}$ and $\mathrm{Hb}$.

\section{Conclusion}

Abnormal 25(OH) D metabolite is commonly seen in Nepalese CKD patients not on dialysis, and that $25(\mathrm{OH})$ 
are directly correlated with male subjects, kidney function, and serum albumin, while inversely linked to age and iPTH. Also, lower level of 25(OH) D have shown to be associated with lower level $\mathrm{Hb}$. The findings indicate that pre-dialysis CKD patients are at a greater risk of developing anemia and hyperparathyroidism, and a timely intervention and proper management of hypovitaminpsosis, especially in elder male population with advanced CKD pre-dialysis patients, is crucial so as to prevent from the disorder that may arise due to $25(\mathrm{OH}) \mathrm{D}$ insufficiency.

\section{Abbreviations \\ Ca: Calcium; CKD: Chronic kidney disease; DBP: Diastolic blood pressure eGFR: Estimated glomerular filtration rate; Hb: Hemoglobin; iPTH: Intact paratahyroid hormone; P: Phosphorous; SBP: Systolic blood pressure}

\section{Acknowledgments}

We thank nephrology unit and the staffs of KMC for helping us during data collection.

\section{Authors' contributions}

SKS: contributed to the design of the protocol, collected data, Performed statistical analysis, interpreted the statistical results, drafted the manuscript. LPA: contributed to the design of the, collected data, supervised during study, interpreted the statistical results, Manuscript revised, All authors approved the final version of the manuscript

\section{Funding}

The authors received no financial support for the research, authorship, and/ or publication of this article.

\section{Availability of data and materials}

The datasets of the current study will be made available from the corresponding author on reasonable request.

\section{Ethics approval and consent to participate}

Study protocol was approved by the Institutional Review Board (IRB) of Kathmandu University and Teaching Hospital. Participants were well aware of the investigation and those who showed willingness to participate in the study voluntarily were consented prior to data collection.

The written consent was taken from each participant prior to data collection.

\section{Consent for publication}

Not applicable.

\section{Competing interests}

The authors declare that they have no competing interests.

\section{Author details}

'Department of Pharmacy, Little Buddha College of Health Science, Purbanchal University, Minbhawan, Kathmandu, Nepal. ${ }^{2}$ Nephrology unit, Department of Medicine Kathmandu Medical Hospital Teaching Hospital, Sinamangal, Kathmandu, Nepal. " ${ }^{3}$ Little Buddha College of Health Science, GPO Box 26508, Minbhawan, Kathmandu, Nepal.

\section{Received: 6 November 2018 Accepted: 1 July 2019}

Published online: 17 July 2019

\section{References}

1. Coresh J, Selvin E, Stevens LA, Manzi J, Kusek JW, Eggers P, et al. Prevalence of chronic kidney disease in the United States. Jama. 2007;298(17):2038-47.

2. Zhang L, Wang F, Wang L, Wang W, Liu B, Liu J, et al. Prevalence of chronic kidney disease in China: a cross-sectional survey. Lancet. 2012;379(9818): $815-22$

3. Otero A, Gayoso P, García F. Prevalence of chronic renal disease in Spain results of the EPIRCE study. Nefrologia. 2010;30(1):78-86.
4. Jafar T, Islam M, Poulter N. Chronic kidney disease in the developing world. N Engl J Med. 2006;354(10):998-9.

5. Zabetakis PM, Nissenson AR. Complications of chronic renal insufficiency: beyond cardiovascular disease. Am J Kidney Dis. 2000;36(6):S31-S8.

6. Moranne O, Froissart M, Rossert J, Gauci C, Boffa J-J, Haymann JP, et al. Timing of onset of CKD-related metabolic complications. J Am Soc Nephrol. 2009;20(1):164-71.

7. McClellan W, Aronoff SL, Bolton WK, Hood S, Lorber DL, Tang KL, et al. The prevalence of anemia in patients with chronic kidney disease. Curr Med Res Opin. 2004;20(9):1501-10.

8. Astor BC, Muntner P, Levin A, Eustace JA, Coresh J. Association of kidney function with anemia: the third National Health and nutrition examination survey (1988-1994). Arch Intern Med. 2002;162(12):1401-8.

9. Kazmi WH, Kausz AT, Khan S, Abichandani R, Ruthazer R, Obrador GT, et al. Anemia: an early complication of chronic renal insufficiency. Am J Kidney Dis. 2001;38(4):803-12.

10. El-Achkar TM, Ohmit SE, Mccullough PA, Crook ED, Brown WW, Grimm R, et al. Higher prevalence of anemia with diabetes mellitus in moderate kidney insufficiency: the kidney early evaluation program. Kidney Int. 2005;67(4): 1483-8.

11. Icardi A, Paoletti E, De Nicola L, Mazzaferro S, Russo R, Cozzolino M. Renal anaemia and EPO hyporesponsiveness associated with vitamin D deficiency: the potential role of inflammation. Nephrol Dial Transplant. 2013;28(7):1672-9.

12. Khaw K-T, Sneyd M-J, Compston J. Bone density parathyroid hormone and 25-hydroxyvitamin D concentrations in middle aged women. BMJ. 1992 305(6848):273-7.

13. Golbahar J, Altayab D, Carreon E, Darwish A. Association of vitamin D deficiency and hyperparathyroidism with anemia: a cross-sectional study. J Blood Med. 2013:4:123.

14. Patel NM, Gutiérrez OM, Andress DL, Coyne DW, Levin A, Wolf M. Vitamin D deficiency and anemia in early chronic kidney disease. Kidney Int. 2010; 77(8):715-20.

15. Kendrick J, Targher G, Smits G, Chonchol M. 25-Hydroxyvitamin D deficiency and inflammation and their association with hemoglobin levels in chronic kidney disease. Am J Nephrol. 2009:30(1):64-72.

16. Souberbielle J-C, Cormier C, Kindermans C, Gao P, Cantor T, Fo F, et al. Vitamin $D$ status and redefining serum parathyroid hormone reference range in the elderly. J Clin Endocrinol Metab. 2001;86(7):3086-90.

17. Vieth $R$, Ladak $Y$, Walfish PG. Age-related changes in the 25-hydroxyvitamin $D$ versus parathyroid hormone relationship suggest a different reason why older adults require more vitamin D. J Clin Endocrinol Metab. 2003;88(1):185-91.

18. Levin A, Bakris G, Molitch M, Smulders M, Tian J, Williams L, et al. Prevalence of abnormal serum vitamin D, PTH, calcium, and phosphorus in patients with chronic kidney disease: results of the study to evaluate early kidney disease. Kidney Int. 2007;71(1):31-8

19. Chonchol M, Scragg R. 25-Hydroxyvitamin D, insulin resistance, and kidney function in the third National Health and nutrition examination survey. Kidney Int. 2007:71(2):134-9.

20. Levey AS, Coresh J, Greene T, Stevens LA, Zhang Y, Hendriksen S, et al. Using standardized serum Creatinine values in the modification of diet in renal disease study equation for estimating glomerular filtration rate. Ann Intern Med. 2006; 145(4):247-54.

21. Levey AS, Coresh J, Balk E, Kausz AT, Levin A, Steffes MW, et al. National Kidney Foundation practice guidelines for chronic kidney disease: evaluation, classification, and stratification. Ann Intern Med. 2003;139(2):137-47.

22. Holick MF. Vitamin D deficiency. N Engl J Med. 2007:357(3):266-81.

23. Ravani P, Malberti F, Tripepi G, Pecchini P, Cutrupi S, Pizzini P, et al. Vitamin D levels and patient outcome in chronic kidney disease. Kidney Int. 2009; 75(1):88-95.

24. Mehrotra R, Kermah D, Budoff M, Salusky IB, Mao SS, Gao YL, et al. Hypovitaminosis D in chronic kidney disease. Clin J Am Soc Nephrol. 2008; 3(4):1144-51.

25. González FA, Sachdeva A, Oliver DA, Martin KJ. Vitamin D insufficiency and deficiency in chronic kidney disease. Am J Nephrol. 2004;24(5):503-10.

26. LaClair RE, Hellman RN, Karp SL, Kraus M, Ofner S, Li Q, et al. Prevalence of calcidiol deficiency in CKD: a cross-sectional study across latitudes in the United States. Am J Kidney Dis. 2005:45(6):1026-33.

27. Chapuy M-C, Preziosi P, Maamer M, Arnaud S, Galan P, Hercberg S, et al. Prevalence of vitamin $D$ insufficiency in an adult normal population. Osteoporos Int. 1997;7(5):439-43. 
28. Dawson-Hughes B, Harris SS, Dallal GE. Plasma calcidiol, season, and serum parathyroid hormone concentrations in healthy elderly men and women. Am J Clin Nutr. 1997;65(1):67-71.

29. Levin A. The treatment of anemia in chronic kidney disease: understandings in 2006. Curr Opin Nephrol Hypertens. 2007;16(3):267-71.

30. Sim JJ, Lac PT, Liu ILA, Meguerditchian SO, Kumar VA, Kujubu DA, et al. Vitamin D deficiency and anemia: a cross-sectional study. Ann Hematol. 2010;89(5):447-52.

31. Reichel H, Koeffler HP, Norman AW. The role of the vitamin D endocrine system in health and disease. N Engl J Med. 1989;320(15):980-91.

\section{Publisher's Note}

Springer Nature remains neutral with regard to jurisdictional claims in published maps and institutional affiliations.

Ready to submit your research? Choose BMC and benefit from:

- fast, convenient online submission

- thorough peer review by experienced researchers in your field

- rapid publication on acceptance

- support for research data, including large and complex data types

- gold Open Access which fosters wider collaboration and increased citations

- maximum visibility for your research: over $100 \mathrm{M}$ website views per year

At $\mathrm{BMC}$, research is always in progress.

Learn more biomedcentral.com/submissions 